\title{
Poetic invention and translation in sixteenth-century England
}

\author{
Rocío G. Sumillera \\ Universitat de València
}

\begin{abstract}
This article investigates the connection between the all-important concept of invention within the literary terminology of sixteenthcentury England and the perception of translation during this period. Invention is discussed as a concept in transition during the sixteenth century, as it was then still associated with the rhetorical notion of "finding" within a topical system, while new shades of meaning closer to imagination, fantasy, fancy and wit started to become dominant even in rhetorical contexts. Invention was deemed in the sixteenth century a necessary ingredient for outstanding poetry, and yet it was assumed to be absent from the work of the translator, whose role was solely to copy the invention of the source text. This article claims that the lack of invention in translations (or rather, the mere following of the invention of the translated text) was the main reason why translations were invariably regarded as minor achievements as compared to their source texts.
\end{abstract}

KEY WORDS: Invention, Renaissance English and French poetics, Renaissance translation, imitation.

\section{Poetic invention and translation in sixteenth-century England}

The term invention had a wide range of meanings in the sixteenth century: it referred to a mental faculty, the application of mental power, its products (such as poems or plays, or other objects unrelated to art), and to the idea behind an artifact or work of art that occurred in the deviser's mind to guide the generative process.

\footnotetext{
(C) ederi 22 (2012: 93-114)

https://doi.org/10.34136/sederi.2012.5
} 
Furthermore, all arts and sciences (poetry included) were considered to have been invented and therefore were inventions themselves, and certainly invention was a praiseworthy aspect in good literary compositions. Ultimately, invention pointed at man's capacity to create in the wider sense of the verb. Inventio, the Latin version of the Greek $\varepsilon \square \rho \varepsilon \sigma l \varsigma$ (meaning "a finding, discovery," or "invention, conception"), was itself related to the verb $\varepsilon \square \rho i \sigma \kappa \omega$ (meaning "to find out, discover" or "devise, invent"). Invention is the first of the five parts of classical rhetoric (inventio, dispositio, elocutio, memoria, and pronuntiatio or actio), and encompasses the three modes of proof (pisteis) or modes of persuasion: ethos, or persuasion through the character of the orator; pathos, persuasion through raising the passions of the audience; and logos, the proofs on which discourse itself depends. Furthermore, "invention" and these topics all belong to the field of dialectic or logic.

In the Renaissance, invention was a necessary requirement for the good orator and the outstanding poet. If through his invention the orator had to discover arguments and proofs, the poet exercised his own invention partly through imitation. The centrality of the concept of poetic invention in the sixteenth century is apparent: invention was a sine qua non for celebrated poetry (i.e., poetry that was elevated to the category of a model), and an indispensable term for poets when reflecting on what made a poetic composition notable. It was also at the core of the dismissive attitudes that translation had to face at the time by a good number of authors and scholars, as this article argues. Of course, the dividing line between inventive writing and translation often becomes extremely fine in the sixteenth century, and as the critic Robert J. Clements concludes in his discussion of the French poetic context, "there might be actually little difference between a creative work and an imitation" (Clements 1942:262). Clements indeed asserts that, in France, "[w]hile the poems presented as original works had a large element of translation in them [...] pieces presented as translations often had a large share of free creation in them" (Clements 1942:262), and that "[s]ometimes the distinction became so fine that the Pléiade poet must have been uncertain whether to call the work a translation or not" - as Clements claims happens with some mid-century translations from Petrarch, which "could be considered either original or plagiarized works, as you wish" (Clements 1942:262). More recently, Lawrence Venuti has claimed that in Early Modern England the hard work of 
the translator became blurred (when not invisible) and insignificant due to the fact that translations strategies were essentially based on the need for fluency above all. Such strategies would ultimately produce an illusion of transparency and agentlessness in translations that contributed to unanimously privilege the status of authors over translators by concealing the efforts and struggles of the latter (Venuti 1994:43).

It needs be admitted that with some of these texts it is sometimes hard for the critic to label a work a translation or a novel invention by an author inspired or influenced by another's writings in a different tongue. On other occasions, the problem arises when comparing an alleged translation with its source text, only to discover the great liberties taken by the translator when rendering the work into a different language which almost make the translation independent from its model. Nevertheless, if in the practice a differentiation between a translation, a version, or an invented composition may be blurry, when focusing on the terminological distinctions present in sixteenth-century meta-literary commentaries, we discover that, at least at a theoretical level, differences do exist between the concepts of translation, imitation, and invented work. Effectively, even if the efforts of the translator or the imitator are acknowledged when their work is of outstanding quality, the highest praise is always awarded to the works produced by the writer's "own invention."

When in the sixteenth century $\mathrm{Du}$ Bellay affirmed that translations were not enough to elevate the status of the French tongue and to put it on a par with the classical languages, but that France needed instead works that sprang from the invention of poets to achieve that feat, he was anticipating the overwhelming relevance of the future concept of "originality." Certainly, even if the much praised sixteenth-century notion of invention is different from the Romantic concept of originality, it still points at what is novel, nonimitative, and non-translated. The fact that in the sixteenth century invention was a requirement for a poet to be crowned with glory and fame explains that imitators of the time tried to make their works pass as inventions, and used their prefaces to highlight their inventiveness. Likewise, it is quite unsurprising that translations frequently advertised themselves as imitations, as in this scheme of thought imitations were less removed from true inventiveness than 
were translations. Invention was hailed as the necessary natural gift for the composition of poetry endowed to a few chosen poets who could of course then be trained in it to improve their poetic skills.

The present article investigates the relationship between the concept of invention and translation in sixteenth-century England. To fully grasp the complex meaning of the notion of invention, in what follows books on rhetoric, poetics, defences of poetry, prefaces to translations, entries to sixteenth-century dictionaries, and literary pieces will be examined. These sources suggest that, at the time, invention was still associated with the rhetorical notion of "finding" within a topical system, while new shades of meaning closer to imagination, fantasy, fancy and wit started to become dominant even in rhetorical contexts. Common to these different kinds of understanding is the centrality of invention in the process of poetry writing, in assessing its literary worth - a trend found in Italian and French as well as English criticism, - and in differentiating an original work from a translation.

The pages that follow will focus on four clearly distinguished ideas regarding the connection between poetic invention and translation. Firstly, for poets and theorists alike, invention was paramount in the process of writing poetry (i.e., fiction). Secondly, invention appears linked to concepts such as imagination, which implies that the human mind was regarded as an active mechanism able to produce images rather freely. Thirdly, the notion that invention and imitation were seen as opposites: while imitation implied repetition of something for which another author was accountable, invention was understood as the production of novelty. Finally, and for the same reason, invention was opposed to translation as well, since the translator was thought to take or borrow the invention of the poet that devised the text to be translated.

\section{Invention in sixteenth-century English dictionaries and books on rhetoric}

During the sixteenth century, a number of monolingual English and other language dictionaries that translated foreign terms into English began to be printed in England. Some of them provide brief definitions of the term "invention," thus going beyond the usual 
one-word translation and offering a fantastic synthesis of the complexity and variation in its meaning over the course of the sixteenth century. The reason why many sixteenth-century dictionaries included it is because of the importance of both logic and rhetoric to the educational system. Indeed, had it not been for the fact that invention was the first of the five-fold traditional division of rhetoric, as well as a fundamental part of logic, fewer sixteenth-century dictionaries would have bothered to include the term. As might be expected, many of these definitions rely on the traditional understanding as the finding of arguments for discussion within the theory of the loci, topics or places. In Thomas Thomas's Dictionarium Linguae Latinae et Anglicanae (1587), for example, Tŏpücē is defined as "[i]nvention or finding out of arguments: the arte of Inuention: a part of Logicke noting the places of inuention" (Thomas 1587:Nnn viiiv), and Inventio as "[a]n inventing, a finding" (Thomas 1587:Hhvii ${ }^{v}$ ). Similarly, John Florio in A World of Words (1598) includes within the definition of tópica that "inuention" can mean the "finding out of arguments" (Florio 1598:Nn3 ${ }^{\mathrm{v}}$ ). The view that rhetorical invention is purely a mental process of finding arguments appears, for instance, in Thomas Wilson's The Arte of Rhetorique, where the term is defined as "a searchyng out of thynges true, or thynges likely, the whiche maie reasonably sette furth a matter, and make it appere probable" (Wilson 1982:31). ${ }^{1}$ At the same time, dictionaries also show how it gradually came to mean not only finding, but also devising something new. For instance, John Baret in his An Alveary or Triple Dictionary, in English, Latin, and French (1574) explains that "[a]n inuetour" is "a deuisour [...] He that inuenteth or deuiseth some new thing" (Baret 1574:Llir). Even Florio's A World of Words, offers a hybrid understanding of it by defining Inuénia as "a deuice, an inuention, a newe found out thing" (Florio 1598:Q6"); Inuentione as "an inuention, a deuise, a forgerie, a surmise, a finding" (Florio 1598:Q6"); and Parto as "the fruite of any mans inuention, whatsoeuer any man or woman brings forth" (Florio 1598: $\mathrm{Y}_{5}^{\mathrm{v}}$ ).

A similar understanding of invention appears in some works on rhetoric which seem to stress a more active side of the psyche in the inventing process, viewing imagination, fantasy, fancy and wit as key mental activities in the development of argumentation. Furthermore, these works understand invention in opposition to

\footnotetext{
${ }^{1}$ Italics throughout are mine.
} 
imitation, and it is often accompanied by the expression "of one's own" to stress the writer's originality. Even though the word "originality" itself is unsurprisingly absent, the emphasis on invention as the antithesis of imitation suggests that innovation underlies the concept of invention.

Invention was indeed regarded in sixteenth-century dictionaries as closely related to the creative and potentially disturbing mental faculty of the imagination. John Baret treats invention and imagination almost as synonyms, explaining imagination in terms of invention, and vice versa. Thus, he elaborates lists of synonyms by comparing "[ $\mathrm{t}] \mathrm{o}$ deuise" to "[t]o imagine: to inuent craftily: to go about deceitfully" (Baret 1574:Tiir), and "[t]o inuent" to "to imagine: to deuise: to feyne" (Baret $1574: \mathrm{Lli}^{\mathrm{r}}$ ). Similarly, Thomas Thomas defines Invenio as to "finde that one seeketh for, to deuise, invent, or imagine" (Thomas 1587:Hhvii ${ }^{\mathrm{V}}$ ), thus including both the rhetoricallogical idea of finding and a more imagination-oriented understanding of invention. Likewise, Richard Perceval in his $A$ Dictionarie in Spanish and English (1599) defines invención as "an inuention, a deuise, a plot imagined" (Perceval 1599:O1r).

Analysing the modifying the term "invention" is also another way to gain an insight into its full meaning. Ralph Lever's The arte of reason rightly termed witcraft (1573) illustrates the implications of the verb "to invent" in the following extract dealing with the creation of new words in English:

For as time doth inuent a newe forme of building, a straunge fashion of apparell, and a newe kinde of artillerie, and munitions: so doe men by consent of speache, frame and deuise new names, fit to make knowen their strange deuises. (Lever 1573:* ${ }^{v}$ )

[...] they that will haue no newe woordes deuised where there is want, seme not well to consider howe speache groweth, or wherefore it was deuised by man: for names are not giuen unto things afore the things themselues be inuented. (Lever 1573:*vii')

Lever shows that inventing implies man's devising of something that did not exist before, something "newe" and "straunge" - a building, a weapon, or words. In The Arte of English Poesie (1589), George Puttenham employs "to devise" in a similar context, when he contrasts writing and translating poetry: "in Chaucer and Lidgate th'one writing the loues of Troylus and Cresseida, th'other of the fall 
of Princes: both by them translated not deuised" (Puttenham 1970:65).

Invention is moreover not only opposed to imitation but praised more highly. In Ortho-epia Gallica: Eliots fruits for the French (1593), for instance, John Eliot praises Homer by saying that "his wit was admirable, his inventions inimitable" (Eliot $1593: \mathrm{G}^{\mathrm{r}}{ }^{\mathrm{r}}$ ). Homer is thus extolled on the grounds that his invention was unique, unrepeatable, non-reproducible, and impossible to emulate and hence surpass.

The connection between invention and poetry is of course not obviated by sixteenth-century lexicographers, who also confirm that invention was regarded as a defining feature of good poetry and an essential characteristic of the poets themselves. For instance, Thomas Thomas defines Pöema as "[a] poets invention, or worke: a poeme: a worke made in verse or rime: verses" (Thomas 1587: $\mathrm{yy}_{5}{ }^{\mathrm{r}}$ ), and Florio explains Poéma as "a poeme, a composition or Poets worke or inuention, a worke in verse or rime" (Florio 1598:Aa4 ${ }^{\mathrm{v}}$ ). In addition to this, invention is frequently juxtaposed to terms such as "wit," "fancy," and "imagination." For example, Thomas defines Ingěnŭum as "wit, wisdome, will, or propertie, fansie, inuention, cunning" (Thomas 1587:Gg2 ${ }^{\mathrm{r}}$ ); Florio explains ingegnóso as "wittie, wilie, ingenious, subtile, wise, cunning, craftie, full of inuention" (Florio 1598:Q1 ${ }^{\mathrm{r}}$ ); and Randle Cotgrave in A Dictionarie of the French and English Tongues (1611) similarly translates Ingeniosité as "[i]ngeniositie, ingeniousnesse, quicknesse of inuention, dexteritie of wit" (Cotgrave 1611:Zz6r ${ }^{\mathrm{r}}$ ). Caught between invention as an essential part of poetry-writing and as a fabricator of lies and deception, sixteenth-century definitions of other terms signal a capacity of an inventive man to compose fables and fictions. In this respect, Thomas Cooper and Thomas Thomas define, respectively, Fabulósitas and Fäbülösütas as "[t]he inuention of fables and lies" (Cooper 1578:Bbb6"; Thomas 1587: $\mathrm{Z1}^{\mathrm{r}}{ }^{\mathrm{r}}$; ; and Florio and Cotgrave explain, respectively, Fabulosità and Fabulosité as "fabulousnes, inuention of sables and lies" (Florio 1598:L2r), and as "[f]abulousnesse; th'inuention of lyes, tales, fables, or fained reports" (Cotgrave 1611:Nn2v). Similarly, Florio defines Fittione as "a fiction, a dissembling, faining or inuention" (Florio 1598: $\mathrm{Mi}^{\mathrm{r}}$ ), and Cotgrave as "[a] fiction, inuention, lie, fib, cog; a thing imagined, fained" (Cotgrave 1611:Oo6v). 


\section{The praise of invention in literary works and poetics}

When taking a close look at the works of literature produced in the sixteenth century, one discovers that the term "invention" very frequently appears in poems, plays, and literary prefaces. In most cases, invention is seen as a necessary requirement for the poet to write something of interest, an ingredient that adds quality and taste to his writings and makes them worth reading. For instance, it appears in George Chapman's The proper difficulty of poetry (1595) as an essential element for a poet, for, to his mind, "absolute Poems" need "not the perspicuous delivery of a lowe inuention; but high, and harty inuention exprest in most significant, and unaffected phrase" (Chapman 1595: $2_{2}{ }^{\mathrm{r}}$ ). Similarly John Davies locates the faculty of invention at the root not only of poetry but as all-encompassing: "maruellous Inuentions," he declares, "doe produce all Artes and Sciences" (Davies 1602:B1 ${ }^{\mathrm{v}}$ ). In Marlowe's Doctor Faustus, "to invent" becomes synonymous with "writing a book," as when Ralph asks, "[w]hy Robin what booke is that?" to which Robin answers "why the most intollerable booke for conjuring that ere was invented by any brimstone divel" (Marlowe 1990:941). Marlowe's choice of term significantly loads the exchange with connotations of feigning and deceit, which may even prevail over the mere idea of encoding information in the written form. John Lyly, in the prologue to Mydas (1632), also makes invention the defining element of plays: "Gentlemen, so nice is the World, that for apparell there is no fashion, for Musique no Instrument, for Diet no Delicate, for Playes no Inuention but breedeth satietie before no one, and contempt before night" (Lyly 1632:T1 ${ }^{\mathrm{r}}$ ). Indeed, these correlations suggest that invention can be regarded as instrumental for poetry, which fits well with Lyly's "rhetorical" idea of fiction, drama and poetry. ${ }^{2}$ Invention is so central that John Davies addresses his "busie inuention" in his epigram 26 ("Of wise fooles, or foolish wise men") requesting it to get to work so that he can write a witty epigram that moves readers to laughter ("invention" is effectively in this case closely related to "wit"):

O! for an Epigram to make the wise

(Like Fooles) laugh at it, till their hearts do breake,

\footnotetext{
${ }^{2}$ See, for instance, King (1955).
} 
VVhy then haue at it; O Inuention rise,

And tickle wisest Heart-strings till they ake. (Davies 1611:B6 ${ }^{\mathrm{r}}$ )

In the same way that rhetorical invention was the first of the parts of rhetoric, invention in a poetical context seems to be what triggers the process of poetic composition. No invention (rather, no good invention) means no chance of coming up with anything worth writing about, hence the poets' often desperate cries for help to the gods or Muses to quicken, illuminate, or brighten up their inventiveness.

When considering works on poetics and defences of poetry we discover that, already in 1538, Thomas Elyot in his The Dictionary of Syr Thomas Eliot Knyght states that Homer's Illiad and Odyssey "are worthy to be radde, for the meruailous inuention, and profytable sentences in them contained" (Elyot 1538:K2v). In other words, the fact that a book has good invention makes it advisable and worthy to be read, which means that already in the first half of the sixteenth century invention was hailed as an independent criterion for assessing literary value. Indeed, Elyot has a rather utilitarian notion of poetry: the allusion to "profytable sentences" directly points at the moral good resulting from reading an author's "meruailous inuention." During the second half of the century, books on poetics continued to stress the importance of invention for a successful literary work. George Gascoigne recognizes it is the starting point of any worthwhile literary work, for without a "fine and good" invention, he doubts that anything praiseworthy will ever result. However, as Gascoigne recognises, it is difficult to explain how to achieve it: "the rule of Invention, which of all other rules is most to be marked, and [yet is] hardest to be prescribed in certayne and

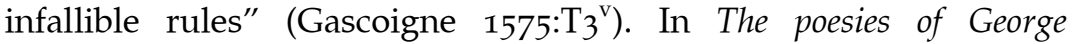
Gascoigne Esquire (1575) Gascoigne stresses the importance of invention on several occasions, for example:

The first and most necessarie poynt that ever I founde meete to be considered in making of a delectable poems is this, to grounde it upon some fine invention. For it is not inough to roll in pleasant woordes, nor yet to thunder in Rym, Ram, Ruff, by letter (quoth my master Chaucer) nor yet to abounde in apt vocables, or epythetes, unlesse the Invention have in it also aliquid salis. By this aliquid salis, I meane some good and fine devise, the wing the quicke capacitie of a writer: (Gascoigne $1575: T 2^{r}$ ) 
Gascoigne seems to understand "fine and good" invention as synonymous with the avoidance of clichés and predictable topics, advocating that writers should approach each topic in a new and witty fashion. ${ }^{3}$ Gascoigne ranks good invention above elocution and rhyme, for invention "beyng founde, pleasant woordes will follow well inough and fast inough" (Gascoigne 1575: ${ }^{\mathrm{v}}{ }^{\mathrm{v}}$ ). Hence, elocution and rhyme are but complements that should not divert the attention of the writer from what ought to be his major concern: invention.

Typically adjectives that accompany "invention" tend to express rareness or oddity, and usually with positive connotations. For example, in the correspondence between Edmund Spenser and Gabriel Harvey published as Three Proper, and Wittie, Familiar letters (1580), when Spenser discusses his intention to write a volume on the route of the River Thames, he highlights that the book "wil be very profitable for the knowledge, and rare for the Invention, and manner of handling" (Spenser 1580:A4 ${ }^{\mathrm{r}}$ ). Likewise, George Puttenham recommends authors that "haue written any thing well or of rare inuention" to publish their works "vnder their names, for reason serues it, and modestie doth not repugne" (Puttenham 1970:22-23). In other words, a work merits publication either if it is well-written or if it possesses "rare invention", that is, if it deals with something different from what other works have previously discussed, from what is trite (hence the adjective "rare"), or if it approaches a familiar theme in an unexpected way.

The relevance of invention also lays at the heart of the Gabriel Harvey-Thomas Nashe quarrel, which lasted for years and has been

\footnotetext{
${ }^{3}$ Certainly, the notion of "wit" appears closely linked to invention in the sixteenth century. In Old English "wit" referred to the mind, and in the plural alluded to the five senses or mental faculties in general. In the sixteenth century, translators rendered into English the Latin voice ingenium as "wit," "especially where the context dealt with rhetoric and the expression of thought" (Crane 1937:9). Indeed, in the latter half of the sixteenth century, "wit was particularly associated with rhetorical devices, such as proverbs, maxims, similes, examples, apophthegms, definitions, and set descriptions," which school rhetoricians used for the amplification and embellishment of topics (Crane 1937:8). Invention for instance appears in Gabriel Harvey's definition of wit as "an affluent spirit, yeelding inuention to praise or dispraise, or anie wayes to discourse (with iudgement) of euerie subiecte" (Harvey 1597:D2 ${ }^{r}$ ). Angel Day's The English Secretorie (1592) relates the concepts of wit and invention too: "[o]f this then the parte especiall and intendment most principall, consisteth, (as by experience is found) in the use and exercise of the Pen, the wit and Invention togethers" (Day 1592:139).
} 
considered "the first English discussion in which accusations and denials of literary theft assumed importance" (White 1973:84). The disagreement began with Nashe's epistle "To the gentlemen students of both Universities" prefixed to Robert Greene's Menaphon (1589). It criticized those who "feed on nought but the crummes that fal from the translators trencher" (Greene $\left.1589:{ }^{* *} 2^{v}\right)$, and those who

must borow inuention of Ariosto, and his Countreymen, take vp choyce of words by exchange in Tullies Tusculane, and the Latine Historiographers store-houses; similitudes, nay whole sheetes and tractacts verbatim, from the plentie of Plutarch and Plinie; and to conclude, their whole methode of writing, from the libertie of Comical fictions [...]. (Greene 1589:**2 ${ }^{\mathrm{v}-* *} 2^{\mathrm{r}}$ )

A few years later, in Pierce Penniless His Supplication to the Devil (1592), Nashe wrote against people's appropriating others' literary property, this time in the context of "stolen" sermons. Indeed, he accuses "some dull headed * Diuines" of having "no eloquence but Tantologies" and "no inuention" (Nash 1592: $\mathrm{Fi}^{\mathrm{r}}$ ). Nashe's attacks finally received a reply in Harvey's Pierce's Supererogation (1593). As Harold Ogden White remarks, in this work Harvey sarcastically praises Nashe's "fresh invention," "new Indies of Invention," "bottomlesse pitt of Invention," "nimble and climbinge reach of Invention," and "socket-worne invention" (White 1973:88), while accusing Nashe of imitating and borrowing from Greene, Lyly, Tarlton, Gascoigne, and Marlowe. The truth is that Harvey was sceptical of Nash's denial and suspected he was actually making use of servile imitation. Nashe, on the other hand, accused Harvey of appropriating material from him and from others. ${ }^{4}$

This emphasis on invention found in English poetics constitutes a feature common to sixteenth-century French and Italian criticism as well. In France, Pléiade poetics appeared before any of the sixteenth-century English examples discussed above, and consolidated many of the views that English authors would later defend in their works, among them, the centrality of invention. For instance, in Art poétique français (1548), Sébillet states that "la sève et le bois [...] sont l'invention et l'éloquence des Poètes" (Sébillet 1990:56). Joachim du Bellay, in his Déffence (1549), regarded

\footnotetext{
${ }^{4}$ For a full account of the Gabriel Harvey-Thomas Nashe quarrel see White (1973:8496).
} 
invention as "premiere, et principale Piece du Harnoys de l'Orateur," and by extension, of the poet too (Du Bellay 2001:86). Jacques Peletier's Art Poétique (1555) affirms that invention "est répandue par tout le Poème, comme le sang par le corps de l'animal: de sorte qu'elle se peut appeler la vie ou l'âme du Poème" (Peletier 1990:252). Thus, establishing an equation in Aristotelian terms, invention is to poetry what mythos is to drama: its very soul. Finally, in Abrégé de l'Art poétique français (1565) Pierre de Ronsard regards invention as an essential element in poetry that springs both from nature and from serious training and awareness of the work of previous writers: "le principal point est l'invention, laquelle vient tant de la bonne nature, que par la leçon des bons et anciens auteurs" (Ronsard 1990:468). Just like Peletier, Ronsard portrays poetry as a living organism, using images drawn from nature and the workings of living bodies: "ainsi la poésie ne peut être plaisante ni parfaite sans belles inventions, descriptions, comparaisons, qui sont les nerfs et la vie du livre qui veut forcer les siècles pour demeurer de toute mémoire victorieux et maître du temps" (Ronsard 1990:471).

In Italian criticism, Ludovico Castelvetro, author of Poetica $d^{\prime}$ Aristotele (1570), is particularly concerned with the importance of invention for writing poetry. ${ }^{5}$ Castelvetro rejects theories of divine poetical inspiration, locates the origin of invention in the mind of the poet, and opposes any form of imitation at the level of invention. According to him, the poet "invents not only the whole plot, i.e., its general design and the disposition of its parts, but also some of the particulars which give it body, not borrowing all of them from others" (Castelvetro 1984:275). Moreover, he believes that "a poet cannot legitimately fashion a plot that merely reproduces that of another poet, and if he does the resulting work would be not a poem but a history or a piece of stolen property" (Castelvetro 1984:42). Indeed, Castelvetro is so against those who consciously appropriate the subject matter and language of others that he calls them thieves, claiming that they do not deserve the appellative of poets as they have no invention of their own:

the person who merely puts a known story into verse shirks the labor of invention; yet invention is the most difficult part of the poet's art, and it seems it was with an eye to the poet as inventor that the

\footnotetext{
${ }^{5}$ As for the situation in Italy on this matter, Ullrich Langer considers the importance of invention in sixteenth-century Italian literary criticism (see Langer 2000:137-138).
} 
Greeks gave him a name that signifies "maker." (Castelvetro 1984:50)

In this way, Castelvetro supports the "real poets," those who "take no notice of other poets, but invent their own matter and their own modes of figurative speech," and dismisses those that "cannot turn their backs on matter previously invented by others or on the figures of speech already used by them" (Castelvetro 1984:41). Thus he conceives of invention and imitation in mutually exclusive terms: if there is no invention in poetry, then there is only imitation, and so, cheeky and dishonest literary fraud.

In the English context, invention was certainly understood as well as contrasting to imitation, for invention is what is followed and imitated by others, as John Lyly suggests in Euphves (1578): "I my selfe haue thought that in diuinitie there coulde bee no eloquence, which I myght imitate, no pleasaunt inuention whiche I might followe" (Lyly 1578:O2 ${ }^{\mathrm{v}}$ ). Edward Blount, editor of Lyly's Six Court Comedies, praises Lyly's works, calling them "six ingots of refined inuention" (Lyly 1632:A4 ${ }^{\mathrm{r}}$ ); "The Lyre he [Lyly] played on, had no borrowed strings" (Lyly 1632:A4 ${ }^{\mathrm{v}}$ ). Similarly, in "To the Gentlemen Students of both Uniuersities," Robert Greene differentiates between those who pass "Ouids and Plutarchs plumes as their owne" from the talented men who need not "borow inuention of Ariosto, and his Countreymen" (Greene $1589:{ }^{* *} 2^{\mathrm{v}}-{ }^{* *} 2^{\mathrm{r}}$ ). More subtly, George Peele repeats this same idea in his story "[h]ow George read a play booke to a Gentleman," included in the posthumously published Merrie Conceited Iests (1627). One of the characters of the tale is a gentleman with "a Poeticall inuention of his owne" (Peele 1627:D3 ${ }^{\mathrm{v}}$ ): in other words, he does not need to borrow other men's inventions.

\section{Invention and translation in the sixteenth-century}

Since Classical Antiquity, the disciplines of grammar and rhetoric had made use of translation exercises for teaching purposes: in grammar, translation was a special aspect of textual commentary or a form of commentary in its own right, and in rhetoric it was an exercise and an art form, a special kind of imitation. Imitation through translation is certainly an active rhetorical faculty of a heuristic nature, for once a text is translated it acquires a kind of primary status, and so can become a rhetorical model in itself. In a 
way, then, it appears that translation can lead to invention: through acute understanding the translator aspires to enter the language of the original, which in its turn is expected to shape the target tongue. ${ }^{6}$ In the Renaissance, the rediscovery of Greek and Latin texts led to engagement with the study of philology and the production of numerous commentaries interpreting the texts. Also, as a result of the emphasis on philology of the earlier humanists, translators of the sixteenth century were deeply concerned with the accuracy of their work and were highly conscious of the special features of every language and of those traits that made every author unique (Sweeting 1964:47; Worth-Stylianou 2000:132). Translation, moreover, became an instrument of mediation between the masterpieces of the past and those to come.

In Renaissance England, translation was also part of the education system in various ways, from the teaching of rhetoric to that of the Classical languages - as Roger Ascham's The Schoolemaster (1570) demonstrates. Additionally, translation was seen in the sixteenth century as an act of patriotism, as a way to make the whole country have access to knowledge ciphered in a different tongue. Thus, for instance, Sir Thomas Wilson, in the preface to The three orations of Demosthenes (1570) explains that he translated Demosthenes because he could not "suffer so noble an Orator and so necessarie a writer for all those that love their Countries libertie, and welfare, to lye hid and unknowne" (Wilson 1570:2 ${ }^{r}$ ). Translation moreover benefitted the entire nation by enlarging the national language's lexicon at a time when vernacular languages aspired to be vehicles of culture and knowledge in same way that Classical tongues were. From this perspective, writing works in English or translating them into English became a means of enriching the language, as the translator was often the one that first noticed the gaps in it and was challenged with the question of how to fill them. The image of England as a nation was therefore tied to the country's

\footnotetext{
${ }^{6}$ Rita Copeland discusses this phenomenon within the Roman context, in which she affirms that "translation is figured as an aggressive hermeneutics: it reinvents Greek eloquentia, it generates new models, it displaces its Greek sources, and in general is described in the active terms of a rhetorical project" (Copeland 1995:34).
} 
tongue itself, and a strong language would influence perceptions of England as a strong country both from within and abroad.?

Despite all the obvious benefits derived from translation, however, translators and poets alike continued to stress the differences between translating and inventing, to the detriment of course of the art of translation. At the heart of the different perception of translation and inventive writing lies the high esteem in which the concept of invention was generally held. The unconditional praise of invention is precisely what elevated literary writings over translations, as translators were thought to follow somebody else's invention in a different tongue. Hence, the basic reasoning was that since translators do not invent but copy the invention of other writers, the work of a translator necessarily remains inferior to that of the author. For this precise reason, James I admits in The essayes of a prentise, in the diuine art of poesie (1584) that his job as a translator cannot be compared to the one carried out by the author he is translating:

Bot sen Inuention, is ane of the cheif vertewis in a Poete, it is best that ze inuent zour awin subiect, zour self, and not to compose of sene subiectis. Especially, translating any thing out of vther language, quhilk doing, ze not onely essay not zour awin ingyne of Inuentioun, bot be the same meanes, ze are bound, as to astaik, to follow that buikis phrasis, quhilk ze translate. (James I 1584: $\mathrm{M}^{\mathrm{v}}$ )

For James I not everybody can become a poet because not everyone has been naturally endowed with the gift of invention: "ze can not haue the Inuentioun except it come of Nature" (James I 1584: ${ }^{\mathrm{r}}{ }^{\mathrm{r}}$ ). This agrees with the common saying that orators were made whereas poets were born; as Thomas Lodge briefly puts it in $A$ defence of poetry, music and stage plays (1579): "Poeta nascitur, Orator fit; as who should say, Poetrye commeth from aboue, from a heauenly seate of a glorious God, unto an excellent creature man: an Orator is but made by exercise" (Lodge 1853:10). From this perspective, then,

\footnotetext{
${ }^{7}$ As Ian Lancashire explains, "the most powerful patron of early modern English was Henry VIII" (Lancashire 2005:30-33), and for over two centuries there existed an informal policy supervised by the Crown "to expand the vocabulary of English by importing words from European languages," through measures such as "awarding patronage to printers of dictionaries and grammars, usually expressed as copyright protection and public approval" (Lancashire 2005:33).
} 
nature becomes the source of poetic talent. In France, Ronsard also believed that "l'invention dépend d'une gentille nature d'esprit" (Ronsard 1990:473), and du Bellay is one of the great champions of poetic invention over translation, as he states that true poets belong to a superior class of men, due to their inventive abilities:

Poëtes, genre d'aucteurs certes, auquel si je sçavoy', ou vouloy' traduyre, je m'adroisseroy' aussi peu à cause de ceste Divinité $d^{\prime I n v e n t i o n, ~ q u ' i l z ~ o n t ~ p l u s ~ q u e ~ l e s ~ a u t r e s, ~ d e ~ c e s t e ~ g r a n d e u r ~ d e ~}$ style, magnificence de motz, gravité de sentences, audace, et varieté de figures, et mil' autres lumieres de Poësie. (Du Bellay 2001:90)

Similarly, George Gascoigne highlights the distinction in the subtitle of his A Hundreth sundrie Flowres bounde op in one small Poesie (1573): "Gathered partely (by translation) in the fyne outlandish Gardins of Euripides, Ouid, Petrarke, Ariosto, and others: and partly by inuention, out of our owne fruitefull Orchardes in Englande." Gascoigne constructs an entire discourse upon the discrepancy between what we would nowadays call creative writing and translating by making the concept of invention a focal point. In "The letter of G. T. to his very friend $\mathrm{H}$. W. concerning this worke" we find numerous occurrences of the term "invention" used in opposition to translation and imitation, and invariably employed with more positive connotations. Thus, when talking about two different works, "[t]he one called, the Sundry lots of loue", "[t]he other of his owne inuencion entituled. The clyming of an Eagles neast," he says that "especially the later [...] doth seeme by the name to be a work worthy the reading" (Gascoigne 1573: $\mathrm{A} 3^{\mathrm{v}}$ ). Tellingly, he speculates whether the author of a sonnet beginning "Loue, hope, and death, do stirre in me such strife" "borowed th'inuentiun of an Jtalian." Despite affirming that "were it a translation or inuention [...] it is both prety and pithy" (Gascoigne 1573: $\mathrm{C}^{\mathrm{v}}$ ), the speaker finally claims to be "sure that he wrote it, for he is no borrower of inuentios" (Gascoigne $1573: \mathrm{F}_{3}{ }^{\mathrm{r}}$ ). When the time comes to judge another sonnet (which begins "The stately Dames of Rome, their Pearles did weare") the speaker is compelled to recognize that, in this case it is indeed "but a translation:" "I am assured that it is but a translation, for I my selfe haue seene the inuention of an Italian" (Gascoigne $1573: \mathrm{F}_{4}^{\mathrm{v}}$ ).

John Harington in Orlando furioso in English heroical verse (1591) admits that he can claim no praise for the invention of the subject matter of his translation, "having but borrowed it" (Harington 
1591:I $8^{r}$ ). In his Arte of English Poesie (1589) George Puttenham's inventory of some of the best well-known English writers begins with the assertion that of the books written by "many of our countrymen" "some appeare to be but bare translatiōs, other some matters of their owne inuention and very commendable" (Puttenham 1970:59). Nevertheless, this does not imply that Puttenham discourages translations. In fact he believes that good translations need to be recognized: "as I would with euery inuettour which is the very Poet to receaue the prayses of his inuention, so would I not haue a trāslatour be ashamed to be acknowen of this translation" (Puttenham 1970:253). Jacques Peletier in his Art Poétique goes even further by affirming that "une bonne Traduction vaut trop mieux qu'une mauvaise invention" (Peletier 1990:263). Peletier was among those authors who recognized translation as a form of imitation, partly because it appropriates someone else's invention:

La plus vraie espèce d'Imitation, c'est de traduire: Car imiter n'est autre chose que vouloir faire ce que fait un Autre: Ainsi que fait $l e$ Traducteur qui s'asservit non seulement á l'Invention d'autrui, mais aussi à la Disposition: et encoré à l'Élocution tant qu'il peut, et tant que lui permet le naturel de la Langue translative. (Peletier 1990:262)

The French poet Agrippa d'Aubigné (1552-1630) proclaimed in his Ode XIII the moral obligation to publicly acknowledge that a text is a translation, rather than original:

C'est beaucoup de bien traduire,

Mais c'est larcin de n'escrire

Au dessus: traduction,

Et puis on ne fait pas croire

Qu'aux femmes et au vulgaire

Que ce soit invention. (D'Aubigné 1952:103; lines 181-186)

Finally, Alexander Neville's preface to his The lamentable tragedie of Oedipus the sonne of Laius Kyng of Thebes (1563) bids the reader not to blame "the grosenes of the Style: neither yet account the Inuentours dylygence disgraced by the Translators negligence" (Neville 1563: $\left.5^{\mathrm{r}}\right)$ : again, the capacity to invent is what first and foremost differentiates a translator from an author. Yet, ironically, the work Neville translates is actually Seneca's version of the Oedipus tragedy, originally of course by Sophocles, who is surprisingly not mentioned at all in Neville's "The Epistle" or the address "To the Reader". In other words, Neville does not allude to the fact that 
Seneca, who is presented as the only and indisputable author (i.e., inventor), had himself borrowed another's invention to write "his" play. Once again, the line separating translation from copying seems an extremely fine one, particularly when, as if in an attempt to gain extra recognition, Neville confesses that he occasionally deviated from the model by employing his "own simple invention:"

I suffred this my base trāslated Tragedie to be published: from his Author in worde and Verse far transformed, though in Sense lytell altred: and yet oftentymes rudely encreased with myne owne symple Invētion more rashly I côfes than wysely, wyshynge to please all: to offende none. (Neville 1563: $\mathrm{A} 8^{\mathrm{v}}$ )

In this manner Neville claims that his own invention is also put to work when translating, quite a bold assertion considering that, as we have seen, in the sixteenth century translation was regarded as not requiring invention at all. With Neville, invention is mostly the product of rhetorical amplification, a strategy that in England was popularized and encouraged by, among other works, Erasmus's De copia and Thomas Wilson's successful Ciceronian and Erasmian volume Arte of Rhetorique.

\section{Conclusion}

In the sixteenth century the concept of invention was at the root of the concept of the "proper" or "authentic" literary text. If an author lacked invention, he was doomed to copy, to imitate previous models producing anything novel. Translation by itself was taken as a form of imitation of a model in a different tongue, as, by definition, translation meant the preservation and following of an author's personal invention. Translators were not meant to invent, but were expected to reproduce a work, albeit using a different linguistic code. From this it follows that the work of a translator could by no means match in difficulty or worth the work of an inventive author precisely because it was assumed that translators did not have to use their inventive faculties. As George Puttenham's work on poetics Arte of English Poesie (1589) declares at the outset,

the very Poet makes and contriues out of his owne braine both the verse and matter of his poeme, and not by any foreine copie or example, as doth the translator, who therefore may well be sayd a versifier, but not a Poet. (Puttenham 1970:3) 
For Puttenham the fact that the true poet "makes and contriues out of his owne braine," that is, "invents," implies a mental effort that is lacking in the act of translation. The translator - for Puttenham as well as for his contemporaries - does not carry out a literary activity that involves creation or tests his imaginative and inventive capacities, but merely limits himself to copying and following. Thus, the translator of literary texts, according to Puttenham, is a simple versifier whose main concern is to accommodate information provided into a predetermined verse structure employing a different tongue. From this point of view, the work of this "versifier" appears more appropriate for a mathematician than for an artist, and far closer to an automatic task not requiring much reflection than to an activity which unquestionably needs the application of the creative faculties of the translator. The appreciation of the demanding work of the translator would only be achieved when translation is acknowledged as an activity that requires the active faculties of the mind in no less measure than inventive writing does. This eventual recognition that translators effectively applied their invention, imagination and creative skills when translating would only occur in the mid-seventeenth century, when the influential neoclassical poets and translators John Denham and Abraham Cowley articulated the goals of the so-called libertine school of translation after a long struggle against the established idea of translation outlined here.

\section{References}

Baret, John 1574. An Aluearie Or Triple Dictionarie: In Englishe, Latin, and French. London: Printed by Henry Denham.

Castelvetro, Ludovico 1984 (1570). On the Art of Poetry. Ed. Andrew Bongiorno. Binghamton: State University of New York, Center for Medieval and Early Renaissance Studies.

Chapman, George 1595. Ouids Banquet of Sence. London: Printed by I[ames] R[oberts] for Richard Smith.

Clements, Robert John 1942. Critical Theory and Practice of the Pléiade. Cambridge: Harvard University Press.

Cooper, Thomas 1578. Thesaurus Linguæ Romanæ $\mathcal{E}$ Britannicæ. London: Printed by Henry Denham.

Copeland, Rita 1995. Rhetoric, Hermeneutics, and Translation in the Middle Ages: Academic Traditions and Vernacular Texts. Cambridge: Cambridge University Press. 
Cotgrave, Randle 1611. A Dictionarie of the French and English Tongues. London: Printed by Adam Islip.

Crane, William G. 1937. Wit and Rhetoric in the Renaissance. New York: Columbia University Press.

D’Aubigné, Agrippa 1952 (1874). Le Printemps: Stances et Odes. Ed. Fernand Desonay. Geneva: Librarie Droz.

Davies, John 1602. Mirum in Modum: A Glimpse of Gods Glorie and the Soules Shape. London: Printed by Valentine Simmes for VVilliam Aspley.

1611. The Scourge of Folly. London: Printed by E[dward] A[llde] for Richard Redmer.

Day, Angel 1592. The English Secretorie, or, Plaine and Direct Method, for the Enditing of all Manner of Epistles or Letters, as Well Familliar as Others. London: Printed by Richard Iones.

Du Bellay, Joachim 2001 (1549). La Deffence, et Illustration de la langue franc $\square$ oyse. Ed. Jean-Charles Monferran. Genève: Droz.

Eliot, John 1593. Ortho-Epia Gallica: Eliots Fruits for the French. London: Printed by [Richard Field for] Iohn VVolfe.

Elyot, Thomas 1538. The Dictionary of Syr Thomas Eliot Knyght. London: Printed by Thomæ Bertheleti.

Florio, John 1598. A VVorlde of Wordes, or most Copious, and Exact Dictionarie in Italian and English. London: Printed by Arnold Hatfield for Edw. Blount.

Gascoigne, George 1573. A Hundreth Sundrie Flowres Bounde Vp in One Small. London: Printed by Henrie Bynneman and Henry Middleton for Richarde Smith.

1575. The Poesies of George Gascoigne Esquire. London: Printed by H. Bynneman for Richard Smith.

Greene, George 1589. Menaphon. London: Printed by T[homas] O[rwin] for Sampson Clarke.

Harington, John 1591. Orlando Furioso. London: Printed by Richard Field.

Harvey, Gabriel 1597. The Trimming of Thomas Nashe Gentleman. London: Printed by E. Allde for Philip Scarlet.

Huarte de San Juan, Juan 1991 (1575). Examen de ingenios para las ciencias. Ed. Felisa Fresco Otero. Madrid: Espasa Calpe.

James I 1584. The Essayes of a Prentise, in the Diuine Art of Poesie. Edinburgh: Printed by Thomas Vautroullier.

King, Walter 1955. "John Lyly and Elizabethan Rhetoric." Studies in Philology 52: 149-161. 
Lancashire, Ian 2005. "Dictionaries and Power from Palsgrave to Johnson." Eds. Jack Lynch and Anne McDermott. Anniversary Essays on Johnson's Dictionary. Cambridge: Cambridge University Press: 24-41.

Langer, Ullrich 2000. “Invention." Ed. Glyn P. Norton. The Cambridge History of Literary Criticism. Cambridge: Cambridge University Press: 136-143.

Lever, Ralph 1573. The Arte of Reason, Rightly Termed, Witcraft. London: Printed by $\mathrm{H}$. Bynneman.

Lodge, Thomas 1853. A Defence of Poetry, Music and Stage-Plays. London: Printed for the Shakespeare Society.

Lyly, John 1578. Euphues. The Anatomy of Voyt. London: Printed by T. East for Gabriel Cawood.

- 1632. Sixe Court Comedies. London: Printed by William Stansby for Edward Blount.

Marlowe, Christopher 1990 (1604). Dr Faustus. Ed. Roma Gill. Oxford: Clarendon.

Nash, Thomas 1592. Pierce Penilesse his Supplication to the Diuell. London: Printed by Abell Ieffes, for Iohn Busbie.

Neville, Alexander 1563. The Lamentable Tragedie of Oedipus the Sonne of Laius Kyng of Thebes out of Seneca. London: Printed in saint Brydes Churchyarde.

Peele, George 1627. Merrie Conceited Iests of George Peele Gentleman. London: Printed by G[eorge] P[urslowe] for F. Faulkner.

Peletier du Mans, Jacques 1990 (1555). “Art Poétique.” Ed. Francis Goyet. Traités de poétique et de rhétorique de la Renaissance. Paris: Librairie Générale Française: 235-344.

— 1950 (1545). "Prefaces to Horace's Ars Poetica, 1545." Ed. Bernard Weinberg. Critical Prefaces of the French Renaissance. Evanston, IL.: Northwestern University Press: 111-115.

Perceval, Richard 1599. A Dictionarie in Spanish and English. London: Printed by Edm. Bollifant.

Puttenham, George 1970 (1589). The Arte of English Poesie. Eds. Gladys Doidge Willcock and Alice Walker. Cambridge: Cambridge University Press.

Ronsard, Pierre de 1990 (1565). "Abrégé de l'Art Poétique Français". Ed. Francis Goyet. Traités de poétique et de rhétorique de la Renaissance. Paris: Librairie Générale Française: 465-493.

Sébillet, Thomas 1990 (1548). "Art Poétique Français." Ed. Francis Goyet. Traités de poétique et de rhétorique de la Renaissance. Paris: Librairie Générale Française: 37-183. 
Spenser, Edmund 1580. Three Proper, and Wittie, Familiar Letters. London: Printed by H. Bynneman.

Sweeting, Elizabeth 1964. Early Tudor Criticism, Linguistic and Literary. New York: Russell \& Russell.

Thomas, Thomas 1587. Dictionarium Linguae Latinae et Anglicanae. London: Printed by Richardum Boyle.

Venuti, Lawrence 1994. Translator's Invisibility: A History of Translation. Florence, KY: Routledge.

White, Harold Ogden 1973. Plagiarism and Imitation during the English Renaissance: A Study in Critical Distinctions. New York: Octagon Books.

Wilson, Thomas 1982 (1553). The Arte of Rhetorique. Ed. Thomas J. Derrick. New York: Garland.

— 1570. The Three Orations of Demosthenes Chiefe Orator among the Grecians, in Fauour of the Olynthians, a People in Thracia, Now Called Romania. London: Printed by Henrie Denham.

Worth-Stylianou, Valerie 2000. "Translatio and Translation in the Renaissance: From Italy to France". Ed. Glyn P. Norton. The Cambridge History of Literary Criticism. Cambridge: Cambridge University Press: 127-135.

How to cite this article:

Sumillera, Rocio G. "Poetic invention and translation in sixteenth-century England." SEDERI 20 (2010): 93-114.

Author's contact: rogusu@uv.es

Submission: 25/o9/2011

Acceptance: 27/01/2012 